\title{
"O QUe eU QUERO É UMA REVOLUÇÃo!": A PERFORMATIVIDADE dE UMA PALAVRA DE ORDEM
}

\author{
Cláudia Madeira \\ FCSH, Universidade Nova de Lisboa, Lisboa, Portugal $^{1}$
}

Este artigo, escrito na primeira pessoa, parte do meu testemunho pessoal, da vivência enquanto cidadã e investigadora social, sobre o ambiente vivido desde 2008 até à atualidade em Portugal, em especial na cidade de Lisboa mas, também, abordando pontualmente alguns exemplos do Porto, Guimarães ou Évora: um contexto de crise social, económica e politica que tem vindo a reactualizar e a restaurar algumas características do imaginário revolucionário do 25 de Abril de 1974, que se apresenta como um "guião" pronto a usar mas, também, a reinventar e questionar. Este ambiente criado (Harvey 2008), vivido e sentido pelo cidadão na sua relação com o espaço público - de que fazem parte as ruas, os espaços culturais, as redes sociais na internet — contém hoje uma intensa performatividade, que é pontuada pela emergência de manifestações a (r)tivistas de base performativa (com diversos graus de mobilização da transformação social), mas também de processos de apagamento ou silenciamento institucional das mesmas. É essa dialéctica que procurarei analisar neste testemunho, cuja base assenta essencialmente da observação "empirica" que decorre da minha vivência quotidiana e da minha experiência como "espetadora".

Palavras chave: artivismo, performance, performatividade, novos movimentos sociais, "guião revolucionário"

\section{"O que eU QUero É uma ReVolução!"}

O título deste artigo teve a sua origem numa frase anónima que vi escrita por duas vezes nas paredes do campus da Universidade de Lisboa. A frase era: "O que eu quero é uma revolução!”. Em qualquer dessas vezes as frases foram apagadas com pinceladas de tinta branca dei-

1 Contato: madeira.claudia@gmail.com 
xando-me apenas a sua memória. Não tive tempo de as fotografar à altura, não sei se alguém o fez, também não sei se foram escritas apenas essas duas vezes ou mesmo se foram escritas pela mesma pessoa.

Aplicando aqui a noção de "psicogeografia", usada nos anos 60 pelo situacionismo debordiano, diria que da primeira vez que vi esta frase, no Verão de 2011, numa parede lateral de um dos edifícios desse campus universitário, relativamente escondida e pequena, uma espécie de nota de pé de página, senti nela um misto de nostalgia e inquietação sobre uma revolução perdida no tempo, - no caso os ideais da Revolução portuguesa do 25 de Abril de 1974, - os quais se procuravam de alguma forma recuperar, e num "novo ciclo" (Madeira, 2012), manifesto pelos "novos" ou "novíssimos" movimentos sociais (Gohn 2009; Raison 2009; Juris et all 2011) que entretanto emergiam em Portugal e no mundo.

Da segunda vez que vi a frase “O que eu quero é uma revolução!", na Primavera de 2012, escrita numa parede mais central do mesmo pólo universitário e com um carácter mais épico, o sentimento onde predominava a nostalgia foi substituído por sensações de maior tensão, em reação ao ambiente vivido em Portugal.

Este artigo resulta assim de várias comunicações que fui apresentando dentro e fora de Portugal sobre esta temática. O que começou como uma "intuição sociológica" e me levou a apresentar na Masterclass Performativity, em Konstanze, na Alemanha, uma comunicação ${ }^{3}$ onde problematizei a emergência de um "novo ciclo" de arte interventiva e performativa que usava como "guião" a revolução do 25 de Abril de 1974", evidenciava-se ao longo do tempo nas ruas e restantes espaços públicos da cidade de Lisboa, onde vivo, mas também em diversos espaços públicos de Portugal. Por diversas vezes, os momentos em que voltei a apresentar a temática foram precedidos ou procedidos de eventos que reafirmavam a sua significância. Vi pela primeira vez "O que eu quero é uma revolução!" quando cheguei de Konstanze, o que me levou a reabordar o tema no II Encontro de Investigação do ICS-UL ${ }^{4}$. Nesse mesmo dia, antes da minha apresentação encontrei um papel anónimo, provavelmente de um(a) jovem investigador(a) - deixado num placard no interior do edifício do Instituto - onde este ou esta se insurgia contra o ambiente crescente de crise política e social em Portugal. Li-o no final da minha apresentação aos meus colegas para demonstrar precisamente essa ideia de "retorno" de uma manifestação performativa e anónima, e lembro-me que nessa altura apenas resultou dali uma discussão mais anedótica que efetiva sobre a crise crescente (o mesmo tinha acontecido em Konstanze), havendo por parte dos meus colegas, internacionais e nacionais, dúvidas sobre a aplicabilidade da ideia de "novo ciclo" e de "guião revolucionário". Quando apresentei outras duas comunicações 5 sobre temáticas próximas fui também informada por uma colega que nas paredes de uma casa de banho feminina do ISCTE-IUL havia uma espécie de "manifesto reivindicativo" (ver imagem 1). Entretanto, em 2013 já não parecia haver dúvidas que Portugal atravessava um outro ciclo de crise política e pela mesma altura que eu publicava o artigo "The 'return' of performance

2 Para o situacionismo a psicogeografia é o "estudo dos efeitos exatos do meio geográfico, conscientemente ordenado ou não, que age diretamente sobre o comportamento afetivo dos indivíduos" (Henrique 1997: 27, veja-se também Debord citado por Cholle 2004:22).

3 "The temporal cycles of social art (in Portugal) - from April 251974 to now" (26 Julho 2011).

4 Numa apresentação que intitulei "O 'retorno social' da performance arte em Portugal - do 25 de Abril à contemporaneidade" (17 Abril 2012).

5 "Feeling Performance in the city" (ICS-IUL, 21 Fev. 2013, no âmbito da Conferência Sensing the city: Explorations in sensory ethnography e "Cycles of Performativities in social movements and their artistic manifestations", no Workshop Protestos e Movimentos Sociais (CIES-ISCTE, 21 Fev. 2013). 
art from a glocal perspective” (2012), nesta mesma revista ${ }^{6}$, em sociologia política era publicado um artigo denominado "Cycles in Politics: Wavelet Analysis of Political Time Series" ${ }^{7}$, onde se reafirmava esta ideia.

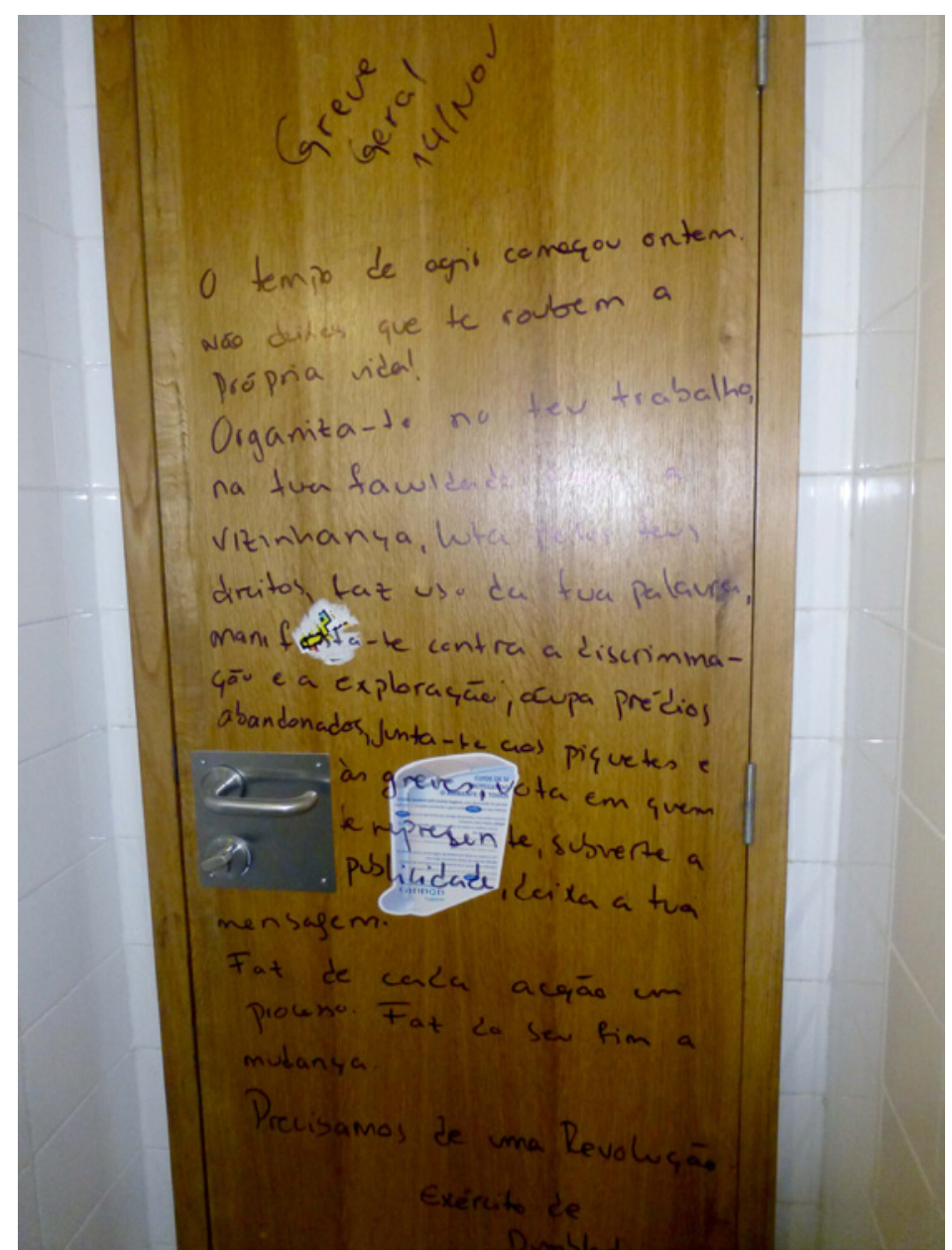

Imagem1. Intervenção na porta da casa de banho feminina. ISCTEIUL, 2013. Fotografia pela autora.

\section{REINVENÇÃo/REENACTMENT/REPERFORMANCE/RETRANSMISSÃo/ RECICLAGEM: "O QUE EU QUERO É UMA REVOLUÇÃo!"}

Um percurso pelo espaço público amplificado da cidade de $\mathrm{Lisboa}^{8}$ permitiu-me refletir sobre algumas das possíveis dimensões de performatividade das palavras e imagens pró-revolucionárias que surgiam predominantemente nas paredes das cidades portuguesas e que serviam de cenário para outras manifestações sociais e protestos performativos. Sintetizo seguidamente

6 E onde aprofundo os conceitos de "ciclo histórico" "performatividade" e "guião", que também servem de enquadramento ao presente artigo, embora este assuma ali um carácter mais empírico,

7 Pedro Magalhães, conjuntamente com Luís Aguiar-Conraria e Maria Joana Soares. 2012.

8 Por espaço público amplificado entenda-se não só os acontecimentos no espaço público físico (grafitis políticos nas paredes, manifestações, etc.) mas, também, a sua disseminação e amplificação através da internet (redes sociais, blogs, etc.). 
três destas dimensões ${ }^{9}$ :

Em primeiro lugar, destaca-se a sua dinâmica cíclica no tempo histórico. Processo que encontra repercussão na noção de "ciclos de hibridação" de Brian Stross (1999) e que remete para a ideia de ciclos que inscrevendo sempre algum grau de hibridez alternam entre formas mais heterogéneas e outras mais homogéneas, sem que nenhuma possa ser considerada uma reprodução simples do processo que retoma. E, também, sem que essas formas remetam necessariamente para um padrão equitativo em todas as esferas do social ou, ainda, para todos os contextos culturais. Nas palavras deste autor: "podemos (...) examinar o processo diacrónico mais longo do que pode ser denominado um 'ciclo de hibridismo': um ciclo que vai de uma forma 'híbrida', de heterogeneidade relativa, para uma forma homogénea, retornando depois novamente a uma forma mais heterogénea" (1999: 265) ${ }^{10}$. Esta noção tem a sua genealogia ligada às noções de "retorno" e de "ciclos históricos" que diversos autores das ciências sociais e humanas ${ }^{11}$ procuraram estudar ao longo do tempo e que teve na Sociologia, nos anos 30, em Pitirim Sorokim um dos seus principais interlocutores, defendendo na sua obra Social and Cultural Dynamics a tese de que "o padrão mais geral de mudança sociocultural é o de processos repetitivos a variar incessantemente", como sejam, "os fenómenos de guerra e paz, períodos de estabilidade e críticos, revolução e reação, autocracia e democracia, individualismo e coletivismo, classicismo e romantismo, idealismo e materialismo, tranquilidade e anarquia, auge e decadência, integração e desintegração, (...)" (1962:83). É importante, sublinhar aqui também, que afirmar a recorrência cíclica destes processos na História não é inconciliável com a noção de "evolução" histórica. Como diz Sorokin: "a História repete-se sempre e nunca se repete” (1969: 577).

Neste enquadramento, a noção de "ciclos híbridos" apresentou-se-me operativa para equacionar a relação entre períodos distantes no tempo, como o período (pré e pós) revolucionário dos anos 70 do século XX e o atual período de crise social e política. Como apresentarei mais à frente, através de exemplos empíricos, em ambos os "ciclos", se verifica na arte e na iconografia anónima disseminada nas ruas um teor subversivo; em ambos os casos, se verifica uma performatividade e efemeridade desses atos que tem características globais, contudo, a par dessas características há sempre novos elementos a serem introduzidos em cada "novo ciclo". Podendo-se afirmar que a reinscrição do imaginário ou "guião" revolucionário passado na atualidade se constitui assim através de memórias "incorporadas” (Diana Taylor 2003), recursivas, impressivas, fragmentárias, híbridas, dinâmicas e, também, especulativas e imaginativas que se, estabelecem, no interior do sistema de socialização de uma sociedade. Hoje, todavia, este "guião" tem a particularidade de se enquadrar no que autores como Anthony Elliot denominam da era

\footnotetext{
9 Aprofundo a primeira destas dimensões, onde reflito sobre noções como "ciclos temporais", "performatividade" e "guião", no artigo "The 'return' of performance art from a glocal perspective" (2012), desta mesma revista. A estas dimensões poder-se-ia ainda acrescentar, por exemplo, a dimensão corporal da performatividade, que como palco de "apresentação do eu", como defendia Erving Goffman (1993 [1959]), e expositor de representações sociais, tanto remete para o corpo individual do protesto, como usa a máscara como "corpo coletivo" e "coral" (como é exemplo, a figura do Anonymos), num processo de desidentificação e de desindividualização. Este "coro" nos novos movimentos e protestos sociais, tal como acontecia na tragédia clássica, canta, dança, fala, sendo que muitas vezes na sua enunciação se dirige a si próprio, como participante e ao mesmo tempo como espectador (Ubersfeld, 2010: 29). Não desenvolvo aqui esta dimensão porque não é dominante nos casos que analiso no presente artigo.

10 Citação traduzida pela autora.

11 Podemos destacar, entre outros, Mircea Eliade, antropólogo, com a sua obra O Mito do Eterno Retorno (1969) onde, no âmbito dessa análise vai citar autores como Friedrich Nietzsche que desenvolve a noção de eterno retorno em várias das suas obras, Spengler, também filósofo, que em 1918, publica The Decline of the West em 1918, e Toynbee, historiador, que entre 1934 e 1961 escreve A Study of History, autores que também inscrevem como núcleo central na sua análise essa ciclicidade.
} 
da "reinvenção" (2013), sendo reativado pela maior acessibilidade a múltiplos arquivos, passados e presentes, disponibilizados, por exemplo, numa simples pesquisa na internet. Aproximandose, analogamente, enquanto dinâmica social, ao que vem sendo discutido nos Estudos de Performance como "reenactement", reperformance ou retransmissão ${ }^{12}$ - onde a repetição de uma performance artística com valor histórico não implica necessariamente um processo mimético do "repertório performativo original", e mesmo quando é essa a intenção do performer, a mudança do contexto temporal e da receção, produz alteridades na nova reapresentação. Por outro lado, tal como vem acontecendo também no domínio da performance arte, onde se verifica um amplificação dos lugares em que este género é apresentado - de espaços da periferia artística (espaços não convencionais e alternativos) para espaços centrais no campo da arte (museus), que fazem emergir novos valores, contrários até à ontologia definida pelos seus percursores ${ }^{13}$ - que assentavam na não reprodutibilidade, visibilidade e valor de mercado -, também se acentuam, neste novo "guião revolucionário" usado pelas práticas artivistas, "novos valores" mais ambíguos ou híbridos, que resultam da mistura dos ideários divergentes da performance artística e da performance social ${ }^{14}$, dando lugar a processos que incorporam quase sempre, ou em potência, o seu contrário, gerando-se assim: (in)visibilidade, (in)formalidade, (des)institucionalidade, (re) criação, (des/re)valorização, (in)temporalidade, etc.

Uma segunda dimensão de performatividade a destacar, e que é complementar à primeira, é a relação entre a arte e o social, ou mesmo entre arte e política. Victor Turner e Richard Schechner (1989) afirmaram a este propósito a existência de uma relação entre estas esferas que não remete para uma relação linear mas uma relação de oposições infinitas e complementares. Esse processo dizem os autores "é responsável pelo modo de produção de invenções e transformações numa dada sociedade. (...) Os filósofos alimentam nesse processo em espiral o seu trabalho; os poetas alimentam-no com poemas; os políticos alimentam-no com os seus atos; e assim por diante" (idem). Já antes, Richard Wagner em "Arte e Revolução" (1849) e Anatoly Lunacharsky em "Revolução e Arte" (1920) falavam numa relação em ziguezague, o primeiro considerando que a arte influenciava a revolução, o segundo que a revolução influenciava a arte. Mais recentemente, Murray Edelman afirma que o artista fornece com a sua obra o ambiente reflexivo para se pensar o social, ou seja, que a arte "suporta um menu de modelos" (Edelman 1995:8) que pode funcionar como "guião" para transformações sociais. Nas suas palavras "os trabalhos artísticos geram ideias acerca de liderança, coragem cobardia, altruísmo, perigo, autoridade, e fantasias acerca do futuro que os indivíduos frequentemente consideram como sendo reflexões da sua própria observação e raciocínio" (Edelman 1995:3).

Em terceiro lugar, destaco ainda a própria dimensão performativa das palavras, no sentido definido por Austin de "atos de fala", assim como o "comportamento restaurado" (Schechner $2003)^{15}$ que lhe é inerente. Efetivamente estas frases que surgem no espaço público, não só re-

12 Veja-se, por exemplo, o livro coletivo coordenado por Amelia Jones e Adrian Heathfield Perform, Repeat, Record: Live Art in History (2012), ou o livro de Philip Auslander Liveness: Performance in a Mediatized Culture (2008).

13 E teorizados, por exemplo, por Peggy Phelan, no seu livro Unmarked (2006).

14 Nesse sentido, a performance, na sua inscrição social, passa a ser um motor que rege todos os domínios das relações sociais desde a sua expressão mais pública, do trabalho ou do lazer até à sua expressão mais privada, da vida pessoal. Processo que tem levado diversos autores a afirmar que a performance é a "nova ideologia" (Heilbrunn 2004: 6) da sociedade contemporânea.

15 Como refere este autor os "hábitos, rituais e rotinas da vida são comportamentos restaurados" (2002: 28), isto é, são comportamentos socializados que se repetem continuamente, sendo que mesmo "o que é 'novo', 'original', 'chocante', ou 'vanguarda' é maioritariamente uma combinação diferente de comportamentos conhecidos ou a deslocação de um comportamento de onde é considerado aceitável ou esperado para um local ou ocasião onde não 
tomaram o "guião" do período revolucionário do 25 de Abril, como procuraram "restaurar" o seu imaginário. Como refere o próprio Austin, sobre a componente performativa dos atos de fala, há neles uma componente ritual e cerimonial que precisa de ser respeitada para se tornar efetiva: "Os [atos de fala] performativos para a sua validação são dependentes de circunstâncias, da mesma forma que um casamento só pode ser efetivo se as palavras corretas forem ditas no tempo certo e no sítio certo, se o tipo de pessoa que o estiver a oficializar for apropriado, se as partes que estão a celebrar o contrato não forem de alguma forma inelegíveis pela idade ou espécie, ou já casadas com outra pessoa" (Austin citado por Loxley 2007:9). Este princípio performativo está presente no facto do próprio ato da escrita numa parede ter um carácter efémero, que não deixa, todavia, de poder ficar na memória de quem lê e de gerar reações.

\section{ReVolução: um "GUIÃo" A USAR E A REINVENTAR}

Através dos exemplos empíricos (de "arquivo histórico" ou que eu própria presenciei ou participei), que apresento seguidamente, procurarei mostrar a forma como estas dimensões de performatividade - que dão corpo a este "guião revolucionário" - ao mesmo tempo que se traduzem numa forma potencial de poder cívico alternativo, à própria política oficial, também, muitas vezes - precisamente porque incorporam uma dimensão de simulacro, fantasmagórica e farsesca, do "guião original" - diluem ou anulam esse mesmo poder.

Começo então por um olhar sobre o período revolucionário dos anos de 1970, em Portugal. Tal como aconteceu nas décadas de 60 e 70 no contexto francês ${ }^{16}$ e novaiorquino ${ }^{17}$, em que o protesto revolucionário criativo se expandiu para a rua, também o período da Revolução portuguesa de 1974 abriu as portas à manifestação criativa do povo nas ruas (que ficou fixada no slogan da altura "a poesia está na rua"). Essa dinâmica levou mesmo à emergência de uma nova iconografia provisória nas ruas da cidade de Lisboa ${ }^{18}$, que representou um novo ambien-

é esperado" (idem).

16 Saliente-se que nesse período os situacionistas: atribuíam às palavras a mesma função de "balas", tinham por palavra de ordem "a revolução ou o terrorismo" (Chollet 2004:80), e viam na emergência de novas expressões artísticas que procuravam fundir a arte com a vida, como o happening, a performance ou mesmo teatro experimental (como os Living Theatre) a "tentativa de atacar de frente o observador na situação e colocá-lo realmente em questão" (Chollet 2004:61), procurando eles próprios criar situações de questionamento da realidade vigente, a que denominavam "derivas". Note-se ainda que a célebre obra de Henri Lefébvre "A vida quotidiana no mundo moderno", escrita em 1967 e editada em 1968, ao mesmo tempo que questionava se a palavra "revolução" não havia perdido o sentido (1969 [1968]: 53) sublinhava os fatores que legitimavam a formulação do projecto revolucionário: "recriar um estilo, reanimar a festa, reunir os fragmentos dispersos da cultura numa metamorfose do quotidiano" (ob. cit.: 55). No pólo oposto da festa, e num contexto repressivo, dizia ainda este autor "emerge o terrorismo" (ob cit.:203). 17 Como refere Berman em Nova Iorque uma "enorme quantidade de arte (...) num grande número de géneros seria feita ao mesmo tempo, sobre a temática da rua e, por vezes, diretamente na rua. (...) E, enquanto isso, uma multidão de executantes surgiu nas ruas tocando instrumentos ou cantando músicas de todos os tipos, dançando, representando ou improvisando peças, criando happenings, ambientes e murais, saturando as ruas. (...) Muitas das manifestações e confrontos dos anos 60 tornaram-se obras notáveis de arte cinética e ambiental, em cuja criação participaram milhões de pessoas anónimas" (1989: 345-346).

18 Num filme entrevista desenvolvido no âmbito de uma exposição denominada "Conceito Incerto" em Dezembro de 1974, o poeta experimental português Ernesto de Melo e Castro referia-se à importância da investigação laboratorial artística que ele considerava tão importante como em ciência, dizendo que, no 25 de Abril (data da Revolução Portuguesa, denominada Revolução de Abril ou dos Cravos), esse laboratório saltou para a rua! Nas suas palavras: "se muitos de nós poetas visuais antes do 25 de Abril nos dedicámos à experimentação laboratorial de certo modo fechada e hermética para o público foi porque o contexto antes do 25 de Abril estava desligado da 
te e cenário performativo de viver a cidade, constituído por pinturas, pichagens clandestinas, cartazes (Pinharanda 2005:41) mas, também, por acções artísticas como a construção de murais artísticos ${ }^{19}$, "enterros de museus" (como o "enterro" do Museu Soares dos Reis, promovido pela Cooperativa Árvore no Porto em 1974) ${ }^{20}$, ou documentários artísticos, como o filme "Revolução" (1977) de Ana Hatherly, construído a partir dos cartazes e grafites que a artista recolheu nas ruas de Lisboa misturando-os com o som de palavras de ordem e música de intervenção, onde se dá conta do ambiente vivido. Para esta artista, antes do 25 de Abril, ninguém se atrevia a "sujar as paredes" e, portanto, para ela as paredes da cidade cheias de grafites e cartazes eram uma representação da voz do povo, da sua revolta contra o fascismo ${ }^{21}$.

Este ambiente revolucionário dos anos 60 e $70^{22}$ do século XX, começou a ser de há alguns anos a esta data "revisitado" por algumas iniciativas performativas. Efetivamente, três anos antes de ver a frase "O que eu quero é uma revolução!" escrita numa parede, tinha assistido, em Lisboa, em 2008, a uma performance do Teatro Lignha, de Hamburgo, produzido pela rádio Antena 2, que aconteceu na Rua Augusta e Terreiro do Paço e que se chamou "À Procura da Revolução Perdida”. No dia 9 de Julho de 2008, ao contrário do que havia acontecido na manhã do 25 de Abril de 1974 em que as rádios portuguesas recomendavam que se permanecesse em casa, a rádio Antena 2 apelava à participação da população para este evento a acontecer nas ruas, com o objetivo específico de rememoração coletiva do imaginário da revolução dos $\operatorname{cravos}^{23}$. O evento contou com a participação de cerca de 200 pessoas que seguindo instruções em pequenos rádios distribuídos pelos organizadores, nessa tarde de Verão, correram, saltaram, deitaram-se no chão, comeram flores ou dançaram no centro da cidade lisboeta. Criou-se assim um espaço de disrupção, eufórico e lúdico, festivo (que eu própria vivenciei) em relação ao quotidiano mais consumista vivido geralmente no centro da cidade. Alguns participantes, como se pode deduzir dos dois depoimentos seguintes ${ }^{24}$ reafirmavam a pertinência do evento para reativar as memórias da revolução:

Devia-se fazer isto todos os anos, precisamente pelo 25 de Abril ... haver uma iniciativa destas, sendo o ponto de partida o quartel do Carmo e acabar aqui no Terreiro do Paço.

Se calhar faz muita falta é uma revolução! Já há muito tempo que a gente devia procurar ... não era só agora, mas enfim, ainda vamos muito a tempo!

criatividade dos homens e das mulheres". Caminhando pelas ruas portuguesas da pós-revolução, Melo e Castro mostrava como a Revolução tinha aberto as portas à manifestação criativa do povo, o que se revelava nas inscrições que apareciam nas paredes e mesmo nos sinais de trânsito, como por exemplo, um sinal de stop onde se acrescentou a palavra "ao fascismo"; a sigla do P.C.P. (Partido Comunista Português) que foi transformada em BOB (num sentido meramente sem sentido); ou ainda a sigla C.D.S. (Partido Popular Conservador) em que o "S" é substituído por um $\$$ (cifrão). Inscrições que pervertendo o seu significado unívoco e normativo ganharam uma assumida carga política. (Madeira, 2012).

19 Ainda que recupere características de outros processos que misturam revolução social e revolução artística, como o muralismo mexicano emergente no início do século XX, protagonizado por Rivera, Orozco e Siqueiros. 20 Veja-se por exemplo sobre este assunto o livro de Gonçalo Couceiro Artes e Revolução - 1974-1979 (2004) onde se descreve este processo. Diz este autor, no ano de 1974 "as ruas enchem-se de cores, siglas murais, cartazes e grafitis". Analiso também no capítulo "Ações revolucionárias" da minha tese de doutoramento O Híbrido nas Artes Performativas em Portugal (Madeira, 2008: 231-249), este ambiente de efervescência criativa e popular nas ruas da cidade.

21 Conversa telefónica com a artista em Outubro de 2010.

22 Que aprofundo no artigo "The 'return' of performance art from a glocal perspective" (2012), desta mesma revista. 23 Vide http://ligna.blogspot.pt/2008/06/in-search-of-lost-revolution.html.

24 Reportagem desenvolvida por Paulo M. Guerrinha e Carla Costa para o site do Sapo. Vide http://videos.sapo.pt/ dJKjizkw3Ki8ONwZtPiZ, data de acesso 10/09/2015. 
Contudo, o seu tom acentuava mais nostalgia do que uma crença efetiva sobre a possibilidade de se recuperar esse imaginário, sendo que no segundo depoimento o próprio acento mais crítico era atenuado pelo riso. De facto, até essa data foram raros os momentos em que emergiu uma abordagem artística mais problematizante sobre o tema da memória colectiva da revolução e da ditadura portuguesa. O período pós-revolucionário em Portugal foi essencialmente caracterizado por uma arte política que dissolveu progressivamente o carácter crítico num carácter satírico e até de farsa. São exemplo, em Portugal, a emergência dos grupos Homeostética e Felizes da $F e ́$, nos anos 80, que, embora mantendo um carácter performativo marcadamente político nos seus eventos públicos, de que o caso mais significativo tem sido a candidatura de Manuel João Vieira à Presidência da República ${ }^{25}$, acentuaram essencialmente a ridicularização das vias democráticas vigentes. $\mathrm{E}$, esse foi, podemos afirmar, o panorama artístico dominante entre os anos de 1980 e meados dos anos 2000, ainda que tenham surgido alguns momentos ou artistas que, com carácter de excecionalidade, procuraram romper e questionar esse silenciamento ou "não inscrição" (José Gil 2005) da memória que se impusera em relação ao tema da ditadura/ revolução. Um desses raros momentos surgiu, por via de um acto de vandalismo da população de Beja, a uma obra de Cristina Mateus, apresentada no âmbito de uma exposição colectiva de arte contemporânea, denominada Além da Água (1997) e comissariada por Jorge Castanho, e que procurava confrontar o Alentejo contemporâneo com um Alentejo do passado, que tivera um papel importante na luta contra a Ditadura. A exposição de fotografia que Cristina Mateus preparou tinha por tema a questão do poder e da ideologia e era introduzida por um tríptico de grandes telões a preto e branco, que foram dispostos na fachada do edifício onde foi apresentada a exposição. Os dois telões laterais eram constituídos por uma imagem idêntica de um silo, com a única diferença que no telão da esquerda se podia ler por cima do silo a palavra "poder" e no telão da direita "ideologia". No telão central apresentava-se a imagem de António de Oliveira Salazar - que foi a figura principal representante do poder durante 40 anos da ditadura fascista em Portugal.

A exposição destes telões acabou por ganhar um cariz performativo pela reação que gerou. Logo na montagem começaram a surgir críticas por parte da população local em relação à exposição em espaço público da imagem de Salazar, tido como um insulto à memória coletiva. E, na própria noite da inauguração da exposição o telão com a imagem de Salazar foi queimado clandestinamente. No dia seguinte, alguns elementos da população que passavam no local riam-se do "ato subversivo" (Cauter 2011) que destruíra a imagem do Ditador. O documentário intitulado Fora de Água, de Catarina Mourão, onde se pode visualizar parte desse processo, termina com uma frase onde se refere que "dias depois da imagem de Salazar ter sido queimada realizou-se na mesma praça uma manifestação de um partido da extrema-esquerda, a UDP²6. Em homenagem a uma das vítimas do Estado Novo, os manifestantes colocaram uma imagem de Catarina Eufémia ${ }^{27}$ no espaço vazio deixado pela imagem queimada" 28 . Neste exemplo específico, paradoxalmente, o ato crítico da obra artística, reduziu-se na mesma medida que se amplificou a reação performativa à obra por parte da população, levando ao ato de substituição de uma imagem negativa da ditadura por uma imagem positiva da revolução.

25 Neste mesmo âmbito Manuel João Vieira escreveu o Livro Rosé de sua santidade o camarada Presidente Vieirarecolha, selecção de textos, conspiração e edição de Pedro Proença, Assírio \& Alvim, Lisboa, 2010.

26 União Democrática Portuguesa.

27 Símbolo da resistência do proletariado rural alentejano à repressão e à exploração do salazarismo, assassinada em 1954 pelas forças do regime fascista.

28 Documentário Fora d'Água de Catarina Mourão, 1997. 
A par desta iniciativa, o artista português que mais significativamente vem trabalhando de forma continuada este imaginário numa perspectiva crítica, é o artista plástico Paulo Mendes. Nomeadamente, através de um conjunto de trabalhos iniciados em 1999, em que desenvolve uma problematização sobre o apagamento da memória, quer da revolução, processo que questionava directamente no próprio título de uma das séries a que denominou $O 25$ de Abril existiu?, e que consistiu na distribuição de autocolantes, criação de imagens em grafitis, exposições, outdoors - alguns dos quais "censurados" pela Câmara Municipal de Lisboa, que o tinha convidado no âmbito de um projecto de arte pública - quer do próprio regime fascista, e da figura do seu ditador, numa série que intitulou $S$ de Saudade. A partir de 2010 este artista vai mesmo desenvolver um conjunto de performances onde corporiza António de Oliveira Salazar na figura do Sr. S. A primeira destas performances chamou-se silêncio, ordens, preces, ameaças, elogios, censuras, razões, que querem que eu compreenda do que eles dizem. A segunda performance, denominada se pudessem parar de fazer para não fazerem nada enquanto não param de todo, o artista utilizava uma série de fotografias suas e de representações do Estado Novo em que as imagens eram passadas por uma tina de tinta branca sendo depois coladas na parede. Em 2011, desenvolve no Museu Militar do Porto, antiga sede da antiga polícia fascista, PIDE, nessa cidade, outra performance denominada a tortura da memória, onde evoca criticamente o passado de repressão e de ausência de liberdade de expressão, associando-o à história contemporânea, de que destaca dois factos: a transformação da principal sede da PIDE, no Chiado, num condomínio de luxo e o processo movido pela família do antigo director da PIDE Silva Pais (1905-1981) contra a autora da peça de teatro $A$ Filha Rebelde e outros elementos do Teatro Nacional D. Maria II, acusados de "ofensa à memória". Estas performances surgem justificadas pelo próprio como ato simbólico de uma memória política histórica portuguesa que na sua óptica continuava a desaparecer sem crítica ${ }^{29}$.

A estes exemplos vieram juntar-se, ainda, dois projetos de 2010 de Hugo Canoilas. O primeiro denominou-se Povo sem título e traduziu-se num processo de colocação clandestina, pelo próprio artista durante a noite, nas ruas da cidade de Lisboa, de peças de um mural que este havia criado para a exposição oficial Povo, apresentada na Fundação EDP, e que era constituído por frases alusivas aos constrangimentos do povo através da voz de diversos artistas e anónimos. Eu própria, depois de ir ver a exposição e de ouvir o comissário João Pinharanda a revelar a intenção do artista de fazer essa acção performativa, encontrei, por um acaso, alguns desses painéis nas ruas perto do Campo Pequeno, em Lisboa, tendo recolhido dois deles. $\mathrm{O}$ segundo projeto coletivo, no qual também participou Paulo Mendes, chamado Jornal Mural, foi distribuído identicamente pelas ruas de Lisboa e teve por objectivo interpelar a população da cidade para notícias de "algo que aconteceu mas que ninguém viu ou que não foi testemunhada na sua totalidade" ${ }^{30}$.

Entretanto, ao mesmo tempo em que estas manifestações artísticas tinham lugar, nesse período, com o agravamento da crise económica e política do país estas frases anónimas tornaram-se uma espécie de "rastilho" e vieram a ganhar em Portugal uma ampla replicação através de um corpus semântico que ergueu uma nova iconografia efémera por todo o espaço público da cidade de Lisboa, desde as paredes das ruas aos cartazes que surgiram nas diversas manifestações até aos blogs da internet e mensagens no telemóvel. "O que eu quero é uma revolução!" tornou-se a partir de então uma das palavras de ordem da vivência quotidiana em Portugal, mas

29 Veja-se a página do artista em http://www.paulomendes.org, acedido a 10/09/2015.

30 Veja-se a notícia sobre este jornal em http://www.ernestodesousa.com/?p=388, acedido a 10/09/2015. 
também global. A questão que se coloca em torno desta frase, e de outras frases que reutilizam o imaginário revolucionário, como por exemplo, "O Povo é quem mais ordena", ou "Classe contra classe" que se podem encontrar hoje no espaço público (ver imagem 2 e 3), é se estas revelam apenas uma estetização de uma palavra de ordem onde predomina o esvaziamento de uma potencialidade transformadora, ou se esta forma de "ativismo artístico" ainda tem algum papel na transformação social. Esta mesma questão tem vindo a servir de mote temático para revistas como a revista Frieze, que dedicou um número a debater a temática Arte e Activismo. No texto de abertura intitulado "Shouts \& Murmurs - Art's disputed relationship to activism”, Jennifer Higgie, coeditora da revista, questiona os que se riem da ideia de que a arte possa ter um efeito real na mudança social: "Como é que a mudança pode acontecer se não for primeiro imaginada? E quem é que poderá assumir que as imaginações andam sobre linhas direitas?” (2012:13). Em suma, esta pergunta parece assumir uma resposta que vê a ação artística como um modo "conjuntivo", expresso por cenários de suposição, desejo, hipótese, possibilidade (Turner 1988:101), que pode ser traduzido pela noção proposta por Irit Rogoff e Florian Schneider (2008) de "antecipação produtiva" - noção que procura caracterizar um estado que é ao mesmo tempo: reflexivo e participativo; não formatado e especulativo (no sentido que não procura fornecer direções de olhar e modos de ver pré-definidos); e por isso com um forte potencial performativo - assente na criação de "ficções sociais" que sirvam cenários alternativos e mais inclusivos, em relação à realidade vigente.

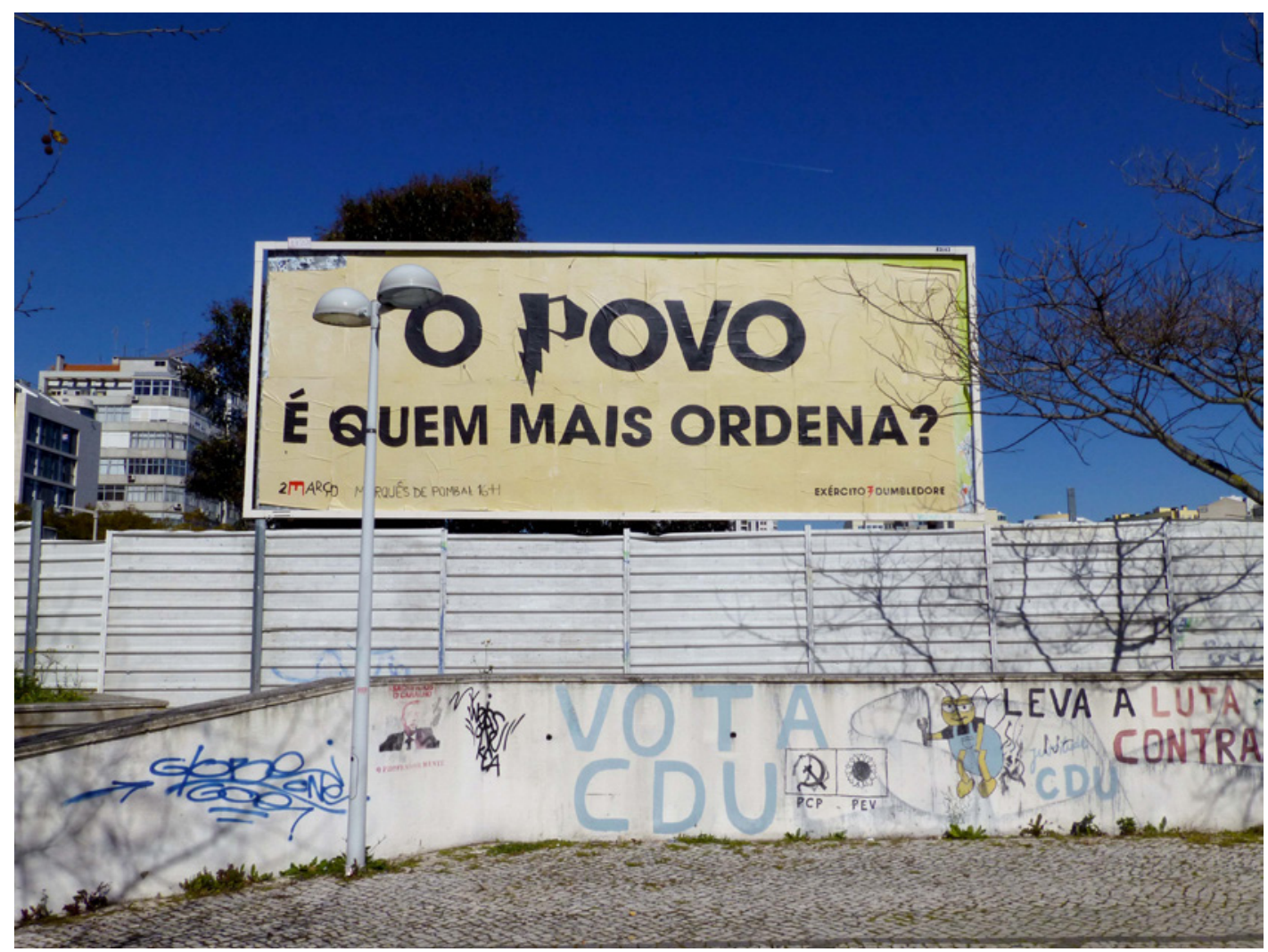

Imagem 2. Grafiti na estação de Comboios de Entrecampos, Lisboa, Março 2013. Fotografia pela autora.

Apesar desse potencial, não é certo que toda a ação artivista tenha uma efetiva capacidade mobilizadora da transformação social e política. Daniel Hamiche num livro escrito precisamente no período dos anos 70, denominado Le Théâtre et la Révolution (1972), onde corrobora 
precisamente a dinâmica de inter-relação entre dimensões sociais ${ }^{31}$, problematiza a relação entre discurso e práticas subjacentes a um "teatro revolucionário". Afirmava este autor, nos anos 70, que o "teatro de vanguarda" e/ ou "revolucionário" não se pode confundir com um teatro de "elites" ou "burguês", na medida em que um "teatro revolucionário" deve manter um cariz "popular”. Nas suas palavras, é sua função "pelos meios próprios ao teatro, ajudar a fazer a revolução proletária e permitir que ele se desenvolva" (1972:16), ou seja, para ser "de vanguarda", o "teatro revolucionário" devia ser "popular".

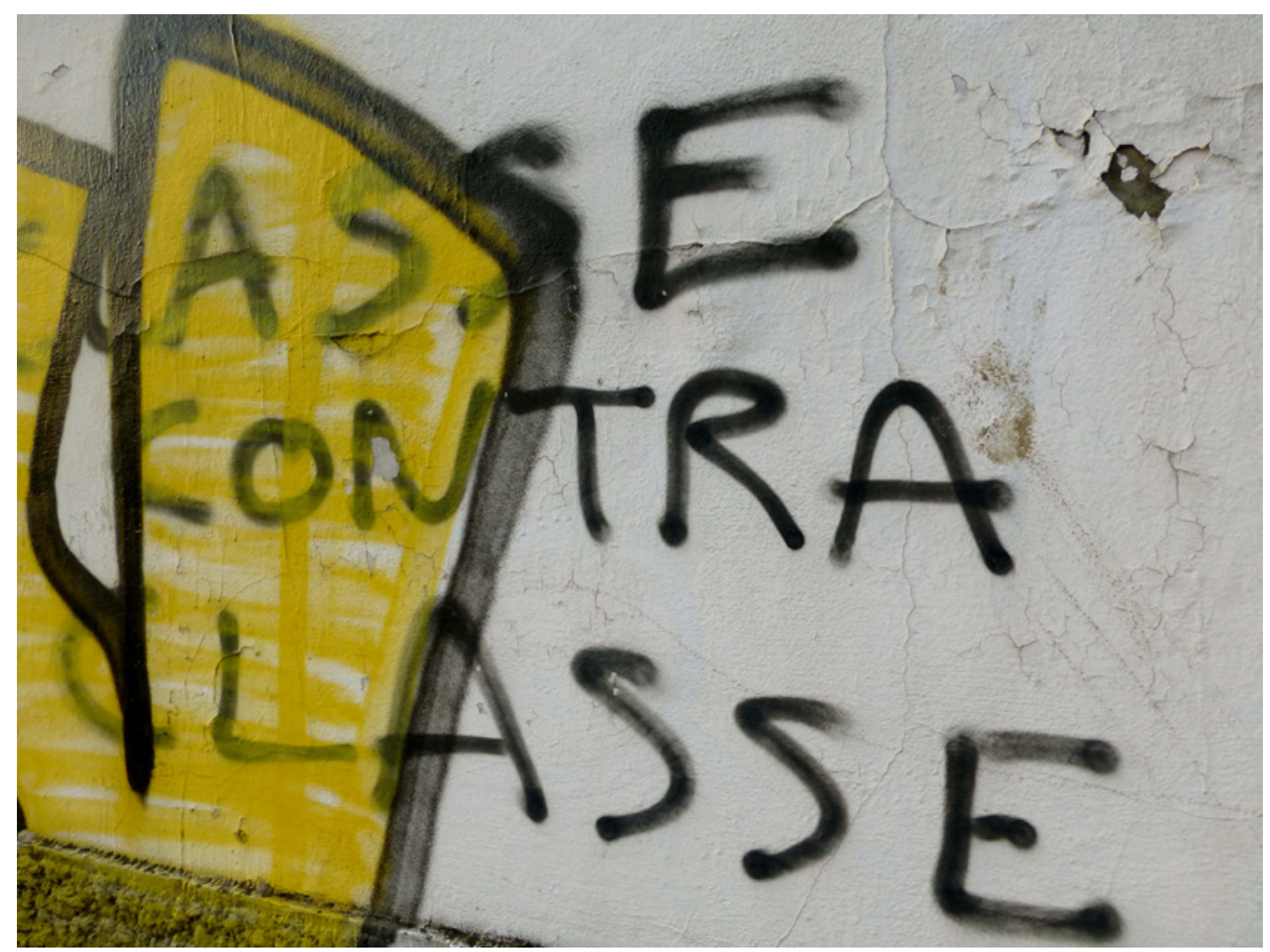

Imagem 3. Grafiti em Lisboa 2013. Fotografia pela autora.

Porém, a verdade é que se procurarmos na contemporaneidade aplicar esta mesma resposta às práticas artivistas atuais teremos as mesmas dificuldades que nos podem levar a questionar-nos sobre a operacionalidade atual de algumas das frases que surgem hoje nas paredes da cidade de Lisboa. Neste contexto, a revolução de 1974 traduz um guião a mimetizar, que não deixa de inscrever em si a alteridade, já que o mimetismo como refere o antropólogo Michael Taussig (1993) não deve ser visto como produtor de uma continuidade histórica, mas como um ressurgimento cíclico que permite um reajustamento do muito antigo com o muito novo. Nesse reajustamento a revolução chega mesmo a traduzir um recurso fantasmático, expresso por exemplo, como vimos, em frases como "classe contra classe" ou "povo" (ou no uso de músicas como as de "Grândola, Vila Morena”, as "grandoladas"), noções que hoje nos surgem bastante mais indefinidas do que no contexto de 1974 , no sentido, em que na contemporaneidade não sabemos bem precisar de que "classes" ou de que "povo" estamos a falar.

31 Citando as Lettres sur le "Capital" onde Engels afirmava que "o desenvolvimento político, jurídico, filosófico, religioso, literário, artístico, etc. repousa sobre o desenvolvimento económico. Mas eles interagem igualmente entre si (...). Não é verdade que apenas a realidade económica seja ativa e que tudo o resto se reduza a ação passiva. Há, pelo contrário, ação recíproca (...)” (Engels citado por Hamiche 1973: 11.) 
Como já afirmava Lefébvre, em 1968, frequentemente, o discurso persiste como fundamento das relações sociais "sem critério, nem veracidade ou autenticidade, nem mesmo objetividade", ou seja, "através de uma nuvem verbal bastante espessa" (Lefébvre 1968: 163) que o esvazia ao mesmo tempo que ilude um preenchimento. Mas, a realidade é que essas frases continuam a ser usadas como nos diz Austin de uma forma "essencialmente mimética, reprodutível" (Austin citado por Loxley 2007:13) já que as palavras e frases "podem ser citadas, ou repetidas para além das suas condições de uso normais" (...), ou seja, elas viajam no tempo e no espaço, nem sempre mantendo uma relação senão simbólica com o contexto original. $\mathrm{Na}$ verdade, os atos de fala, como os expressos nestas frases, não mudam o seu potencial, mas o contexto onde eles são produzidos são cada vez menos ritualizados e difusos (Alexander 2006) e os signos cada vez mais incertos, esvaziados e imprevistos. Neste sentido, eles tornam-se cada vez menos eficazes introduzindo elementos de ativação e desativação, que esvaziam parte do potencial performativo e transformativo.

De facto, não nos podemos esquecer que em 1974 nem os cartazes e murais eram idênticos às frases e imagens que hoje proliferam (e sob novas dimensões) pelo espaço público, nem mesmo representações e incorporações desde as "mascaras" aos "coros" tinham exatamente as mesmas expressividades. Num artigo de 1979, de José Manuel Pedreirinho, intitulado "Grafismo e política em Portugal (Propaganda mural de 1974 a 1976)" isso fica bem explícito. Alguns dos murais, especialmente, os produzidos pelos grupos de extrema-esquerda, remetem tematicamente para a "utilização da força física, seja por figuras humanas - homens e mulheres, supermusculados - seja pela também muito frequente utilização de armas", "as figuras apresentam-se com grande dinamismo, frequentemente mesmo com violência, avançado para o espectador", noutros sublinhava-se a "glorificação do partido, com especial destaque para a bandeira" e era também "muito frequente a presença de soldados e marinheiros armados lado a lado com a população civil”. Algumas destas imagens remetiam para uma intenção de atuação muito imediata e efémera, versando temas da atualidade, muitas vezes, ligadas aos objetivos dos pequenos partidos, com referências aos seus momentos pontualmente importantes na vida política nacional, outras incidindo e mantendo uma atualidade prolongada no tempo onde os temas se interligavam a uma produção física do trabalho. Numa reportagem jornalística para a revista do jornal Expresso denominada Descubra as diferenças ${ }^{32}$ o sociólogo Tiago Fernandes, reforçava esta ideia, apontando como elo de ligação entre os dois períodos históricos, a existência de "uma continuidade extrema nos slogans ('o povo unido jamais será vencido') e nos princípios que foram desenvolvidos durante a revolução portuguesa”, enquanto, Elísio Estanque, acentuando as diferenças entre os dois períodos, referia a evidente "despolitização partidária dos movimentos" e a substituição da noção de povo por um "nova classe mais instruída e terciarizada que em nada remete para o tempo do 25 de Abril”.

Esse olhar para o passado, para o sublinhar de uma "Revolução Incompleta", acentua a falência e esvaziamento do ideário da Revolução Francesa, que em 1789, se centrava no conceito de "esperança" no "futuro" na Europa e nas Américas (Burke 2012: 4). Nos nossos tempos globalizados, baseados em "mediascapes” (Appadurai 2004 (1996): 54) que providenciam repertórios extensivos e complexos de imagens e ideias para audiências pelo mundo, permitindo um tipo de "olhar total" onde tudo (incluindo o passado) se torna contemporâneo, criam-se as bases para o reforço de uma noção de "presente contínuo" que é, essencialmente, dominado por "pastiche" e "nostalgia” (Calabrese 1999 (1987): 194).

32 Reportagem assinada pelo jornalista Miguel Pereira para a Revista do Jornal Expresso, datada de 20/10/2012. 


\section{REVOLUÇÃo: INSCRIÇÃo e APAGAMENTO}

Seja no contexto da criatividade artística ou na "popular" ou "anónima" configura-se entre arte e social um espaço de interação que assenta a sua eficácia ritual em códigos e memórias partilhadas que se substancializa, para além dos fatores já enunciados acima, em "comportamentos restaurados" (Schechner, 2003) 33 , convencionados e reiterados no tempo. Esse factor pode explicar a repetição sistemática, como se de uma espécie de coro trágico se tratasse, de um guião de citações de revoluções passadas - como "revolução", "rebelião", "povo", "popular" ou mesmo "classe" - , assim como a recursividade, quer da relativa semiclandestinidade presente na inscrição desta iconografia nas ruas, quer da recursividade do seu apagamento, especialmente junto a lugares de poder.

Independentemente da relativa traduzibilidade e operacionalidade destas palavras de ordem, a verdade é que as palavras são ações, parte activa da vida quotidiana — repositórios onde se podem refletir valores "aspiracionais" (Appadurai 2008) implícitos numa ideia de utopia de transformação social (Bauman 2008) ${ }^{34}$ - e, por isso, passíveis de atos de apagamento pelas autoridades. Uma dicotomia entre expressão pública/ desordem e propriedade privada/ ordem alimenta frequentemente este processo através do ideário de uma sociedade capitalista assente na maximização da propriedade privada.

Apresento aqui outros exemplos, onde esta dialética de inscrição e apagamento é evidenciada: em Março de 2013, surge num enorme outdoor, perto da estação de comboios de Entrecampos, em Lisboa, a frase "O Povo é quem mais ordena" (ver imagem 2), tendo sido limpo poucos dias depois; em Julho do mesmo ano, os grafitis reivindicativos que tinham coberto as fachadas das instituições universitárias do centro da cidade de Lisboa, foram também limpos sob o pretexto de final de ano letivo, ficando à altura apenas alguns restos de cartazes no chão que desapareceram no tempo. Do mesmo modo, nas zonas "tradicionais" de acolhimento das manifestações sociais os grafitis políticos desapareceram por baixo de pinceladas de tinta, deixando indícios da sua existência em alguns bairros "mais alternativos", como o Bairro Alto, onde surgiam alguns grafitis com a máxima "ocupar São Bento" 35 (ver imagem 4). Uma das fachadas da Faculdade de Ciências Socias e Humanas da Universidade Nova de Lisboa, onde tem prevalecido uma "tradição" de grafiti reivindicativo e político, viu a substituição desse cenário por um enorme mural alusivo à data da comemoração dos 40 anos do 25 de Abril, em 2014, tendo como figura central Salgueiro Maia, o icónico "Capitão de Abril” da Revolução de 1974. O mural encomendado pela Faculdade à plataforma artística Underdogs, ao mesmo tempo que reforçou uma imagem democrática da Universidade, pareceu produzir uma "imagem monumento" de desincentivo às expressões anónimas dos grafitis políticos. Uma grande frase a preto que dizia “ \pm O Futuro é para sempre \pm ” de Miguel Januário ainda esteve durante alguns dias a complementar este mural mas, em pouco tempo, desapareceu também sob novas pinceladas de tinta branca.

33 Veja-se a nota de rodapé 7.

34 Num texto denominado "Living in Utopia" Zgmund Bauman problematiza a operacionalidade da expressão utopia na contemporaneidade referindo que "para nascer, o sonho utópico precisa de duas condições: o sentimento de que o mundo não está a funcionar de forma apropriada e, em segundo lugar, a confiança de que os homens podem mudar as coisas" (2008:317-318).

35 Esta frase remetia para a ideia de ocupar a Assembleia da República Portuguesa que é sedeada na Rua de São Bento, em Lisboa. 


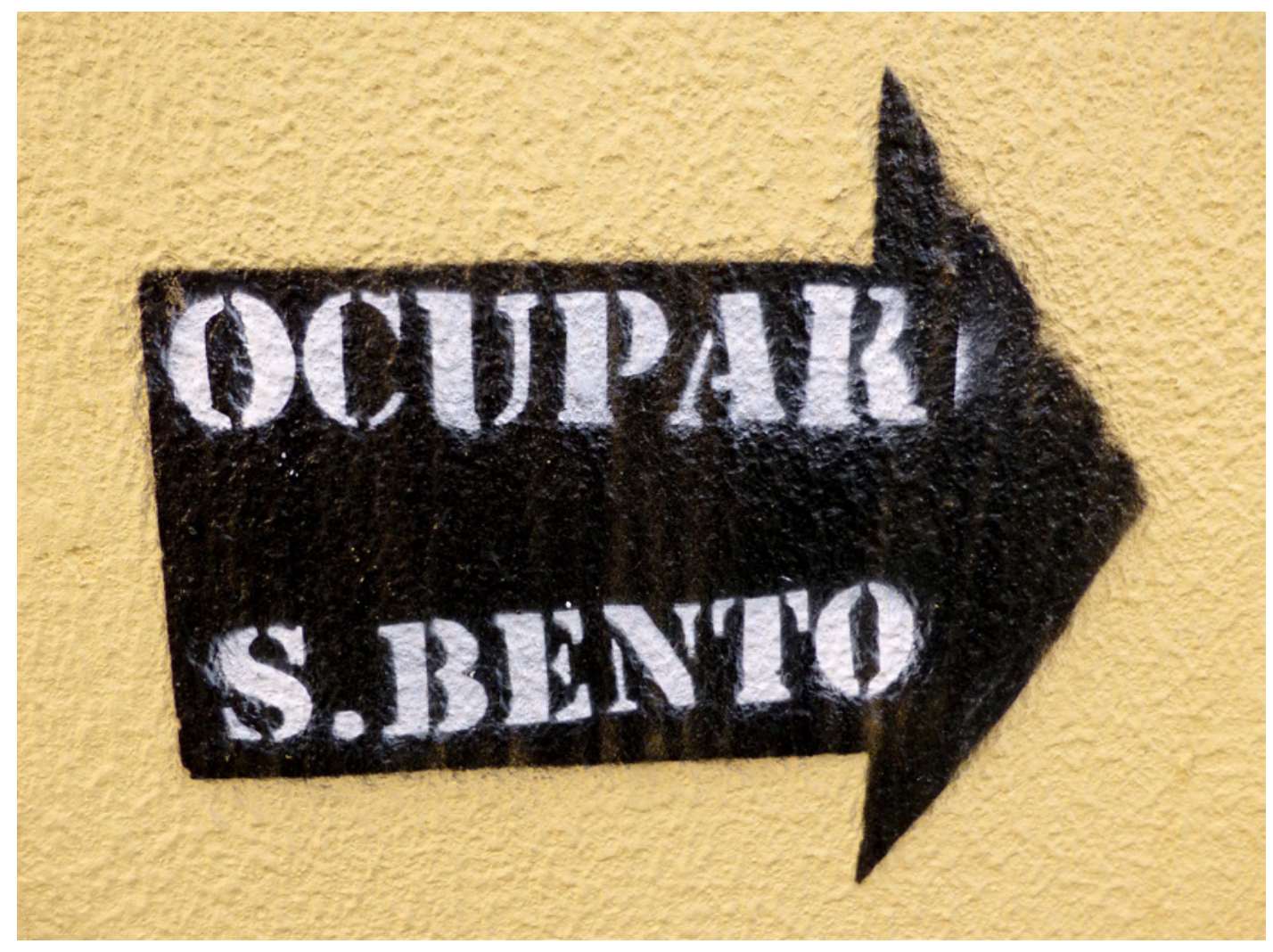

Imagem 4. Grafiti no Bairro Alto, Lisboa, 2013. Fotografia pela autora.

Mais recentemente a Revista de Imprensa Social, do Instituto de Ciências Sociais da Universidade de $\mathrm{Lisboa}^{36}$, foi também alvo de acesa polémica pelo facto do Director do mesmo Instituto ter tentado suspender a publicação de um número da revista onde constava um ensaio visual do sociólogo Ricardo Campos, intitulado "A luta voltou ao muro" onde este apresentava seis fotografias de grafitis políticos portugueses com um pequeno texto que as introduzia ${ }^{37}$. As fotografias que ilustram este "ensaio visual" traduzem uma amostra das muitas imagens que se podem ver nas ruas, algumas contemplam injúrias à classe política e económica, mas não deixam por isso de ser representativas do clima social e político e das imagens que qualquer cidadão pode ver, especialmente no centro da cidade de Lisboa. A revista acabou por ser publicada com este ensaio visual. Não sofreu o mesmo acto de apagamento dos grafitis por ter sido aí defendido o princípio de liberdade, da "universalidade", e do carácter público da investigação científica, em detrimento de uma lógica de privatização dos espaços e das discussões públicas.

Presenciei também um desses atos performativos de apagamento, que tive oportunidade de fotografar por telemóvel, numa viagem a Évora. Um agente municipal pintava com tinta

36 Análise Social, 212, XLIX (3.), 2014.

37 Neste texto o autor referia: "Nos últimos anos parece ter despontado nas paredes uma nova vontade de comunicação política. A grave crise económica e social que eclodiu em função das fortes medidas de austeridade impostas pela coligação de governo $\mathrm{PSD}-\mathrm{CDS}$ parece ter mobilizado os cidadãos para atuarem politicamente à margem dos mecanismos convencionais de expressão e vontade política. As grandes manifestações que se realizaram nos últimos anos, organizadas por associações e coletivos não partidários são um bom exemplo disso. As paredes parecem, também elas, servir cada vez mais para expressar não apenas uma revolta difusa, mas para acicatar o poder político, satirizar a classe partidária e afrontar o status quo. Através de palavras, de slogans, de murais pintados a aerossol ou através da técnica do stencil, vários são os exemplos destas manifestações que pude recolher nas ruas de Lisboa. As imagens fotográficas que aqui se reproduzem visam precisamente, retratar esta dinâmica de manifestação popular" (Campos:2014). 
branca uma parede onde se lia a frase "o povo é roubado e gosta morre à fome" (ver imagem 5). Note-se que já alguém tinha substituído a expressão "gosta" por "morre à fome", num acto de performatividade, que teve o seu acto final, no apagamento da mesma.

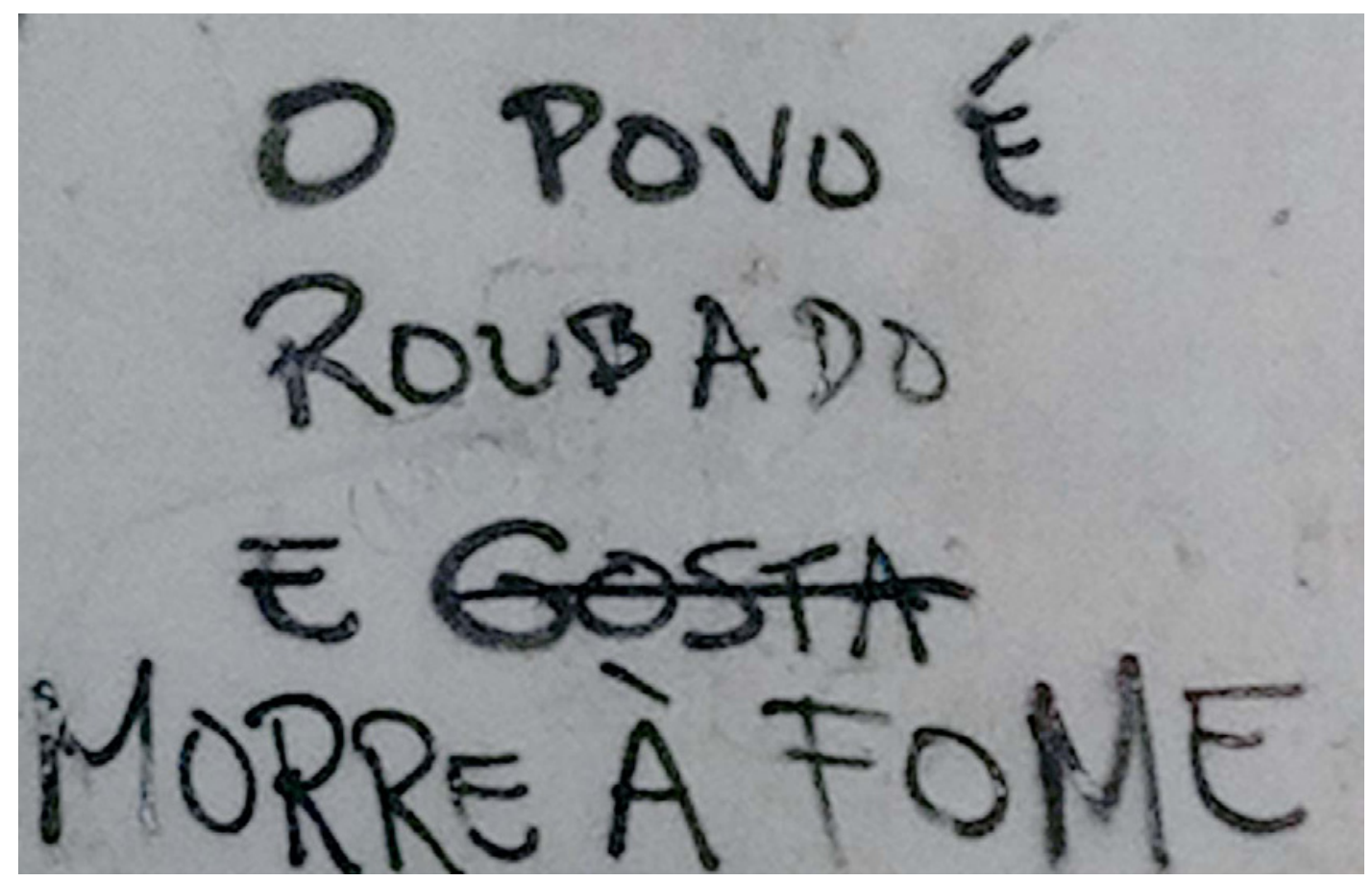

Imagem 5. Grafiti em Évora, Abril 2014. Fotografia pela autora.

O "guião revolucionário" tem ressurgido continuamente não só na escrita nas paredes e nas ruas, nas manifestações políticas e nos "novos movimentos sociais" onde surgem ações performativas, tanto preparadas, como mais ou menos espontâneas (com a sua extensão ao espaço da internet), mas também, nas redes sociais como o Facebook e até nos lugares mais institucionais da arte, como os teatros e museus, assumindo uma posição variável de transgressão, subversão e denúncia política, onde o carácter lúdico, a sátira, a paródia e o absurdo se encontram frequentemente presentes. Apresento de seguida mais exemplos, entre vários, que dão conta destes factores.

Em Setembro de 2012, alguns meses depois de ter visto pela segunda vez a frase "o que eu quero é uma revolução!", surgia na rua em frente da Assembleia da República uma "marcha de soldados", de brinquedos de plástico, organizada por um grupo de artistas denominado Colectivo Negativo, que retomava o slogan usado por Salgueiro Maia, o icónico "Capitão de Abril" da revolução de 1974: "Somos todos comandantes, somos todos capitães". Em 2014, nas comemorações dos 40 anos do 25 de Abril, várias iniciativas tiveram lugar em Lisboa. Entre elas a ocupação da TSF, uma acção que aconteceu por iniciativa da própria direcção desta rádio que convidou o teatro o Bando a homenagear o processo revolucionário do 25 de Abril de 1974, que foi difundido pela rádio. Cerca de 50 actores profissionais e amadores leram excertos de livros de vários autores portugueses alusivos ao tema da revolução. A iniciativa mais uma vez inscreveu um carácter essencialmente lúdico.

Pedro Xavier - O Herói Anónimo de 1974, constitui-se como uma espécie de fotonovela interativa que surgiu a partir da plataforma do Facebook do Teatro Maria Matos, em Lisboa. Pedro Xavier foi o nome dado ao personagem fictício que se apresentava como a viver o mês anterior 
ao 25 de Abril de 1974, na clandestinidade fugido à Guerra Colonial e à procura de Luísa, fugida à PIDE, cujo contacto perdeu quando se exilou ${ }^{38}$. Através deste mote amoroso cruza-se uma história social e política pensada como se em 1974 já existissem redes sociais como o Facebook e este "herói anónimo" escrevesse diariamente, durante os 30 dias anteriores à Revolução ${ }^{39}$ os seus pensamentos e vivências. O processo de criação da "dramaturgia" utiliza o próprio dispositivo interativo desta rede social: é publicitado no Facebook institucional do Teatro Maria Matos, como um evento desta organização a acontecer "só" nessa plataforma, convidando os seus públicos a tornarem-se "amigos" de Pedro Xavier (na página criada para o efeito), e a seguirem a história construída no seu mural, participando nela, quer através de comentários aos posts do personagem, quer através do envio de fotografias pessoais da altura do 25 de Abril, assim como os seus testemunhos, que foram posteriormente seleccionados pelos autores da novela (Dulce Maria Cardoso e Luís Mário Lopes) para fazerem parte do enredo. O processo terminou no dia 25 de Abril de 2014 onde foi anunciada a participação de Pedro na Revolução de Abril de 1974 (e o final feliz do seu encontro com Luísa) ${ }^{40}$.

No mesmo período, duas outras iniciativas tiveram lugar, desta feita usando o dispositivo da internet, uma delas também de carácter predominantemente lúdico, outra mais crítica.

O trabalho do poeta experimental António Barros, artista que fez parte do grupo Po-Ex dos anos 60-70, tem vindo também a retomar um papel de crítica política e social ao contexto português, procurando "denunciar" as condições socioeconómicas dos portugueses, o seu poder menor perante o poder dos representantes políticos e o papel da arte nesse contexto de crise. É exemplo, o trabalho desenvolvido também no âmbito das comemorações dos 40 anos do 25 de Abril, em que o artista inseriu na página do seu Facebook pessoal, um a um, 40 poemas visuais em cravos $^{41}$ negros, enviando-os depois num livro para a Assembleia da República, sob o título Lástima. $^{42}$

As performances nas manifestações sociais e o seu registo na internet têm vindo também a ser recenseadas por diversos jovens investigadores que tratam a questão dos movimentos sociais e/ou que investigam performance arte. É o caso de Vera Soares ${ }^{43}$ ou do trabalho de Rui Mourão (2014). Este último tem vindo mesmo a assumir uma dupla faceta de "artista-investigador", tendo exibido no Museu do Chiado uma vídeo-instalação denominada Os Nossos sonhos não cabem nas vossas urnas, conjuntamente com um livro editado pelo Museu denominado Ensaio de Artivismo - Video e Performance (2014) e com a apresentação dos seus responsáveis: David Santos e Emília Tavares, onde recenseou e apresentou 10 performances artivistas. No mesmo

38 Ouve-se no trailer que abre este projeto: "A Luísa deixou de me escrever, tenho de regressar a Portugal, não importa o risco que corro, tenho de regressar. Maldita a hora em que saí do país e maldita a Guerra que me fez fugir. Não se deve viver longe de quem se ama. O que é que te aconteceu Luísa, onde estás? (Pedro Xavier, trailer). 39 O período de 24 de Março a 25 de Abril de 2014 pretendeu representar o mesmo período, mas no ano de 1974. $40 \mathrm{E}$ também revelado o nome dos autores do projeto até aí anónimos, e a possibilidade dos seus seguidores puderem, nesse dia, ter com eles uma conversa "real" no Teatro Maria Matos.

41 O símbolo da Revolução do 25 de Abril, também denominada Revolução dos Cravos.

42 Antes disso já tinha "postado" uma fotomontagem de Amália Rodrigues com uma lágrima, tendo iniciado esse processo de crítica política através de uma recolha dos grafitis das ruas da cidade de Coimbra de 2011 a que chamou de "urban collage" intitulada mudos os tempos, mudas as vontades. Já depois de Abril de 2014 apresentou também na sua página do Facebook, as obras Portugal: Braço(a)deus_Palavras nuas; A Poesia Está na Rua”, 40 anos depois, BN - A Bandeira Nacional [Estudo de requalificação], e Portugal no seu melhor.

43 Esta autora apresentou uma comunicação a que assisti denominada "Espetacularidade e performatividade na cena contemporânea dos Movimentos Sociais Portugueses", no âmbito do Workshop Protestos e Movimentos Sociais Contemporâneos em Portugal, que decorreu nos dias 20-21 de Fevereiro 2013, CIES-IUL. 
acto de inauguração desta instalação acabou por produzir uma nova acção de artivismo onde apresentou um "manifesto contra o estado cultural vigente em Portugal", com a participação activa de alguns visitantes e convidados da inauguração da exposição, que "ocuparam" o museu durante uma noite até à chegada da polícia no dia seguinte. Apesar de no manifesto escrito se poder ler: "estamos aqui em defesa do museu e não contra o museu" e de se fazer através dele uma denúncia à desvalorização e empobrecimento da cultura e das suas instituições, a acção acabou por ser mal acolhida pela Direcção do museu, facto que levou Rui Mourão a referir "Não se pode fazer uma revolução sem causar incómodos". ${ }^{4}$

Uma das novidades do uso deste "guião revolucionário" na contemporaneidade é também o cenário em que estas manifestações artivistas acontecem. Enquanto no 25 de Abril de 1974 se anunciavam, como vimos atrás, "enterros de museus" que aconteciam fora dos muros dos ditos museus, hoje este espaço artístico institucional, dos museus, dos teatros, ou mesmo das Expos (cidades capital europeia da Cultura), tem também vindo a ter um papel cada vez mais relevante nestas práticas artísticas de intervenção social, partilhando (com maior ou menor intensidade) algumas características de activismo ainda que, precisamente, por se caracterizarem por este estatuto intramuros do campo artístico, este processo tenha sido menos recenseado por estes novos investigadores. Nestes espaços, podemos destacar entre outros: A Noite do Manifesto, desenvolvida no dia 14 de Abril de 2012, no Teatro Maria Matos ${ }^{45}$, tendo sido aí lidos diversos manifestos históricos, como: o Manifesto do Partido Comunista de Marx e Engels de 1848 (lido por Mónica Calle), o Manifesto contra o trabalho do grupo Krisis, de 1999 (Ana Borralho e João Galante) ou A última mensagem ao Povo da Guiné e Cabo Verde, de Amílcar Cabral, de 1973 (Flávia Gusmão e Chullage); mas, também, diversas performances da dupla Ana Borralho e João Galante, como: art piss, no money and politcs $(2012)^{46}$; \pm Estalo novo $(2013)^{47}$; Purgatório (2013) $)^{48}$ e Aqui Estamos Nós (2014) ${ }^{49}$ onde a temática da "representação", nas suas componentes artísticas, sociais e políticas é problematizada.

44 Veja-se o artigo de Cláudia Carvalho no jornal Público "Museu do Chiado esteve ocupado toda a noite contra a situação atual na Cultura", de 06/07/2014.

45 Onde vários artistas dispõem no chão várias fotocópias de jornais com notícias e imagens de política e de economia da atualidade e lhe "mijam em cima", com a participação inclusive de alguns espectadores, gerando durante meses uma intensa polémica em espaço público. Participaram neste evento Ana Borralho e João Galante, Bruno Bravo, David Pereira Bastos, Dinis Machado, Flávia Gusmão, Guilherme Garrido, Há.Que. Dizê-Lo, Lula Pena, Mónica Calle, Rui Catalão, Sofia Dinger, Sónia Baptista, Tiago Rodrigues, Victor Rua.

46 Vide http://vimeo.com/62237213, acedido a 30/12/2014.

47 Espetáculo apresentado no Centro Cultural de Belém (nos dias 28, 29 e 30 de Novembro de 2013), interpretado pela Companhia Maior, uma companhia de teatro composta por uma população sénior e onde se cruzaram memórias públicas e privadas dos dois ciclos da ditadura e revolução de 1974 e da crise atual.

48 Apresentada entre os dias 4 a 6 Outubro de 2013 na Culturgest, onde enquanto o público que assistia sentado no chão de uma sala de estar do centro cultural podia comer amendoins e deitar as cascas para o chão, os artistas de costas para estes, nus, durante cerca de uma hora, questionavam a palavra que unia artistas e políticos: performance. 49 Apresentada entre os dias 21 a 23 de Novembro de 2014 traduzindo-se uma performance participada pelo público como um grupo de investigação que iria retomar uma pesquisa científica iniciada em 1974 pelo controverso psicólogo Salomon Hoffman, que teria estado em Portugal durante o período da revolução. Durante o espetáculo o público foi convidado a participar nas ações em palco e a discutir e mesmo votar, por exemplo, "se considerava que expressões como igualdade e liberdade se equivaliam", "se seria capaz de cometer um ato de violência em nome da liberdade", "se preferia morrer com culpa ou com medo", "se tinha medo que as suas perguntas no leito de morte fossem uma pergunta sem resposta", "se sentia mais medo do desconhecido ou do conhecido", "se alguma vez tinha visto alguém nu em cima de um palco ou se seria capaz de se despir à frente de desconhecidos", "qual achava ser a melhor roupa para desobedecer a uma ordem", "quando foi a última vez que desobedeceu a uma ordem" ou "qual achava ser a diferença entre culpa e vergonha", entre outras questões. 
Também o artista Miguel Januário tem desenvolvido diversas atos que podem ser considerados artivistas, que vão desde frases de grafitis políticos (como apresentamos atrás), até uma performance coletiva e simbólica onde se fez o "enterro de Portugal", através do projecto \pm PORTUGAL 1143-2012 \pm , em plena "cidade berço" de Portugal, no âmbito da EXPO Guimarães 2012. Num registo na internet ${ }^{50}$ pode ver-se esta performance por capítulos: no I capítulo, chamado Aviso, vêem-se imagens de edifícios abandonados em cima dos quais vai aparecendo uma legenda a negro que adapta o hino nacional português ${ }^{51}$. No II capítulo, denominado Traição vê-se a população na rua a sucumbir no chão. No III, A Repressão, ouve-se a música "o Povo unido jamais será vencido", com imagens de um rebanho de ovelhas (que transporta os símbolos \pm e da Comunidade Europeia) a ser conduzido por polícias pelas cidade, até ser fechado num camião. No IV Capítulo, denominado Morte, assiste-se então à procissão do enterro do país, simbolicamente representado por um caixão negro com a forma de Portugal. A "procissão" é acompanhada por carpideiras que choram a morte do país e por uma guarda de honra, da Guarda Nacional Republicana, terminando a performance (perto da muralha onde se lê "aqui nasceu Portugal") com o som dos tiros próprios de um evento oficial. As futuras acções, depois desta morte de Portugal, traduziriam, segundo Miguel Januário, a "ressurreição" e a "reconquista" do país, e seriam acções que surgiriam como motes para os portugueses se "Auto revolucionarem”. Paradoxalmente, esta participação aparentemente lúdica da Guarda Nacional Republicana acabou por levar à abertura de um processo de averiguações que terminou com a exoneração do comandante territorial de Braga.

Um outro exemplo, que se pode inscrever numa espécie de artivismo light cujo cenário é institucional, é o caso do espetáculo Uma revista à portuguesa do Teatro Praga - Tropa Fandanga (2014), encomendado pela direção do Teatro Nacional Dona Maria II e apresentado na sala principal deste teatro. Este espetáculo desenvolvido pelo Teatro Praga, uma companhia de teatro contemporâneo portuguesa, faz uma reactualização do género revista, mantendo o tom caricatural, paródico e satírico do género, procedendo assim a uma crítica de costumes a uma certa "portugalidade" 52 através de um texto inédito construído, em co-autoria pelos vários elementos do grupo, em cima do tema que lhes foi proposto pela direção deste Teatro: a comemoração dos 40 anos do fim da Guerra Colonial e dos 100 anos do início da primeira Guerra Mundial. O mote da guerra tornou-se fórmula onde couberam afirmações sobre a crise atual que proliferaram no espetáculo, de que são exemplo: "o mundo é uma panela de pressão, é como aquela senhora grávida que está prestes a explodir", "guerra ao desemprego", "a guerra serve para espalhar a palavra: portugalidade", "nós queremos uma revista revolucionária", "mais vale estar em guerra do que em crise", onde se encaixou o "tema sério" que faz parte da própria estrutura da revista à portuguesa, apresentado por Joana Manuel, a partir da intervenção que esta tinha feito no dia 23 de Fevereiro de 2013, no Auditório da Faculdade de Ciências de Lisboa, no quadro da Conferência Nacional - "em defesa de um Portugal soberano e desenvolvido" 53 .

50 Veja-se em http://www.maismenos.net/portugal.php, acedido a 30/12/2014.

51 No qual se pode ler: "Ireis pagar pobre povo, nação doente e mortal, leiloai hoje de novo, o ex-valor de plutogal, entre as lacunas da memória, ó pátria sente-se atroz o sortilégio posto a vós, que há-de reduzir-te à história, às lamas, às lamas, se sobrar terra e sobrar mar. Às lamas, às lamas, se a pátria restar, contra os barões lutar, lutar". 52 Este tom de farsa já estava também presente na peça Ubus - Um contributo para a desdramatização da pátria, de Ricardo Pais que este apresentara no Teatro Nacional São João do Porto em 2005, de que partilhou um excerto no seu Facebook no dia 25 de Abril de 2014.

53 Onde Joana Manuel fala de uma geração de pais que viveram num regime de ditadura e empobrecimento e que são hoje a rede de sustento a jovens que parecem nunca deixar de ser jovens devido à precaridade, ao desemprego e a falta de horizontes em Portugal que continua a emigrar. Uma geração que the "deu alimento" e que the "ensinou a contar que o povo é quem mais ordena. 
Também a peça de Vera Mantero, Salário Máximo (2014), apresentada no próprio espaço onde decorrem as sessões parlamentares na Assembleia da República Portuguesa se pode inscrever neste espaço dilatado de artivismo. Tomando o formato híbrido de um espetáculo-instalação-conferência, Vera Mantero começa por mostrar ao "público" presente, que se sentara nas cadeiras parlamentares, uma folha onde se podia ler "a desigualdade empobrece o país", para depois contar que fora proibida, de ser fotografada com essa folha na mão nas escadarias da Assembleia da República para uma reportagem para o jornal Público, pela guarda oficial que assegura a segurança da Assembleia. E, por isso, no âmbito da peça, deixou-se fotografar com esse mesmo cartaz nesse espaço oficial do poder político pelos telemóveis dos espectadores que, entretanto, disseminaram a imagem pelas suas redes sociais. Esta conferência/performance, como a artista começa por referir não procurou tratar tanto da questão de um "salário máximo" (como dá a entender o seu título), como discutir "a questão de proporção entre salário mínimo e salário máximo", uma vez que Portugal se apresenta hoje como um dos países mais desiguais em termos salariais na Europa. A sua palestra vai, portanto, abordar as consequências económicas e sociais do empobrecimento da população ilustrando (através dos vários televisores existentes no Parlamento), esses factos com imagens de gráficos que mostram essas diferenças no espaço europeu. Depois vai cantar uma canção do "guião revolucionário" da década de 70 no palanque central do Parlamento sobre o valor do trabalho. ${ }^{54}$ No final da peça convida o público a ver a "instalação" que fez de cenário ao espetáculo, que é composta por folhas que contêm afirmações e citações factuais, retiradas de artigos e livros de economia (como "nos países mais desiguais é maior a taxa de homicídios" ou "os países mais desiguais têm piores resultados em matemática e literacia”), imagens de gráficos que ilustram essas desigualdades e ainda partituras de músicas de intervenção, e apela a que os espectadores levem consigo essas folhas, como memória do espetáculo.

É sobre esta mesma temática do "empobrecimento da população portuguesa" que Paulo Mendes e Emília Tavares desenvolveram também a exposição coletiva denominada O Tempo e o Modo, no Pavilhão 31, do Hospital Júlio de Matos, em Lisboa, e inaugurada em 16 Janeiro de 2015. Vários artistas e também investigadores sociais participaram na elaboração desta iniciativa, nomeadamente, Hugo Canoilas, que reapresenta alguns dos seus painéis com frases alusivas aos constrangimentos vivenciados pelo Povo (similares aos que apresentara em 2010 na exposição Povo, na Fundação EDP, e que distribuíra clandestinamente pelas ruas da cidade de Lisboa), ou João Tabarra que apresentou um vídeo-instalação onde ele próprio performatiza "um sem-abrigo".

54 Tratou-se da Canção Sem Maneiras, cuja letra é a seguinte: "Senhores, sou mulher de trabalho, e falo com poucas maneiras./ Porque as maneiras são como a luva que calça o ladrão./ Às vezes, eu ponho-me a pensar na vida das trabalhadeiras./ E nas canseiras com que ganhamos a fome e o pão./ Há tanta gente como eu, tantos que pensam como eu./ E a minoria que nos rouba e mente são os burgueses que mandam na gente./ Cravos, gravatas e bonés, nunca vi tantos rapa-pés,/ Enquanto for o burguês a mandar(i), é o fascismo que vai regressar./ Senhores, sou mulher de trabalho, e falo prás trabalhadeiras/Sem as maneiras dos democratas da governação./ Às vezes, cheguei a acreditar, que a nova democracia./ Acabaria com o fascismo e a exploração./ Mas s'isto assim continuar, com os patrões a comandar./ $\mathrm{O}$ desemprego e a carestia, são os canhões que nos querem matar./ $\mathrm{E}$ enquanto nos dizem pra votar, já está o burguês a preparar/ outro fascismo de cara mudada, enquanto a gente anda assim enganada./ Senhores, sou mulher de trabalho, estou farta dessas brincadeiras,/são só maneiras de nos prenderem com outro cangaç(o)./ Às vezes, eu ponho-me a falar, e digo às minhas companheiras,/ [que há] outras maneiras de nos unirmos pra dar mais um passo./ Vamos lutar e sanear, vamos ser nós a comandar,/Com esta luta por um mundo novo, e os operários [camponeses] à frente a guiar./E há tanta gente pra lutar, p'la democracia popular,/ Que não há falsos amigos do povo, que nos impeçam de um dia ganhar./ E há tanta gente pra lutar, p'la democracia popular,/ Que não há falsos amigos do povo, que nos impeçam de um dia ganhar. 
Outros projectos ainda assentam sobre a necessidade de se constituir um museu para a (pós-) memória portuguesa. É o caso da peça de Joana Craveiro, intitulada Um museu vivo de memórias pequenas e esquecidas - sobre a ditadura, a revolução e o processo revolucionário, apresentada nos dias 13,14, 15 e 16 de Novembro, de 2014, no espaço Negócio, no centro de Lisboa, onde esta encenadora e actriz parte da sua própria história familiar e pessoal para desenvolver uma pesquisa em torno da memória coletiva portuguesa, apresentando uma listagem de temas onde a sua história familiar privada se cruza com a história coletiva, como: "as fotografias escolares das crianças nascidas nos anos 70 em Portugal que eram tiradas tendo como pano de fundo os Montes Suíços"; as "coisas chinesas" que tinha na casa de família, nomeadamente, um livro vermelho de Mao, dos seus pais; o "silêncio e medo imposto pela Ditadura"; "os brandos costumes dos portugueses"; as "perseguições PIDE" políticos"; "a guerra colonial"; "os massacres de Tete"; "o exílio"; "as manifestações de estudantes da Praça do Chile", "as lutas da independência nos países africanos"; "a ocupação da rádio no 25 de Abril"; "o escrever nas paredes, depois do 25 de Abril de 1974"; "o turismo revolucionário dos fotógrafos e jornalistas mundiais que se deslocaram a Portugal e que vinham ver a revolução dos cravos"; "os retornados"; "o stress pós-traumático dos militares que participaram na guerra"; "as comissões de moradores", e, por fim, "o silêncio atual sobre estes temas e a necessidade de se falar sobre eles". No final do espetáculo, que geralmente acontecia por volta da meia-noite (depois de cinco horas de espetáculo apenas interrompidas por um "jantar comunitário") a encenadora abria um debate com a plateia onde se revelavam outras histórias pessoais contadas pelos espectadores onde se destacavam temas como, as "perseguições, prisões e torturas", os "medos" e os "silenciamentos da memória coletiva", discutindo-se, por exemplo, "a placa que anuncia o edifício da ex-PIDE, em Lisboa, que foi retirada do local anonimamente por diversas vezes". Uma frase é dita neste espetáculo que retrata bem a dialética entre inscrição e apagamento destas atividades no espaço público onde se inscrevem todos estes atos de intervenção artística que venho enumerando neste artigo: "a história é fruto do poder. A marca última do poder talvez seja a sua invisibilidade".

A estes espetáculos, alguns como vimos, que ocorrem dentro de instituições de poder político ou artístico, junta-se ainda uma linha assumidamente de performance arte, na qual podemos destacar, quer os projetos de performance desenvolvidos por Susana Chiocca, quer os trabalhos de reperformance que têm sido desenvolvidos pela coreógrafa Vânia Rovisco, no âmbito de um ciclo denominado Reation to time. No que diz respeito à primeira, em 2005, a performer apresentava uma ação performativa na galeria Boavista, do Porto, intitulada $\mathrm{O}$ circo vai desaparecer?, que foi complementada com a distribuição e colagem de cartazes e flyers na rua e sua difusão via email, que tinha por objetivo fazer uma crítica política ao governo. Alguns anos depois, em 2011, vai desenvolver nas paredes dessa mesma galeria o ato de escrita-performance à espera que o nevoeiro passe, numa alusão ao contexto de crise português, e em 2013, desenvolveu numa praça em Amesterdão um ato performativo que chamou Não temos de morrer, onde arremessava contra uma fotografia de Ângela Merkel, colada no chão, vários pequenos galos de Barcelos refletindo assim a tensão político-social vivida na Europa. No caso da segunda, podemos destacar a re-performance com que a coreógrafa abre o ciclo Reaction to Time, a 15 de Janeiro de 2015, no Museu Arpad Szenes / Vieira da Silva, onde trabalha sobre a transmissão de uma peça que Manoel Barbosa, um dos percursores da performance arte em Portugal nos anos 70-80, apresentara no pós 25 de Abril no Encóntro Internacional de la Creación Libre de Barcelona (1975), denominada Identificación, onde o tema também tratava de mostrar sim-

55 Polícia política do regime fascista português. 
bolicamente o longo e monótono percurso que os personagens (que retratavam os portugueses) descaracterizados, vestidos todos de igual e com passos mecanizados "de marioneta", tiveram de percorrer durante a Ditadura até poderem quebrar o "espelho" onde se olhavam.

\section{ReVoluÇão: Um PALCo PARA MÚltiplas ReACÇões e EFEITOS}

Em suma, este "guião revolucionário" parece construir-se a partir do que Maffesoli denomina o retorno do "grande fantasma da universalidade trágica", onde o Homem se revê de novo indefeso em relação a um destino que não controla (e cuja criação não pode mais atribuir aos deuses porque é resultado da ação dos próprios homens). Frases como “ \pm O Futuro é para sempre \pm " escritas e depois apagadas de uma parede da Faculdade de Ciências Sociais e Humanas no centro da cidade de Lisboa parecem traduzir essa falência de um ideário esperançoso de futuro, substituindo-o por um futuro incerto.

Esta perspetiva do "retorno do trágico" que tem a sua genealogia na frase com que Marx abre $O 18$ de Brumário de Louis Bonaparte onde afirma que a história se repete, uma vez, como tragédia, outra vez, como farsa ${ }^{56}$, tem encontrado eco também em autores como Georges Steiner, em A morte da Tragédia (2006 [1961]), Jean Marie Domenach, em Le Retour du Tragique (1967), Slavoj Žižek, em Da tragédia à Farsa (2010). Para estes autores, este retorno encontra o seu espaço na "farsa" e no "absurdo". Como refere, por exemplo, Domenach, o nascimento da tragédia contemporânea tem a sua origem no extremo oposto da própria tragédia, ou seja, no cómico, e especialmente nas suas formas mais subalternas, da farsa e da paródia (Domenach 1967: 256).

É próprio da "farsa" e da "paródia", e mesmo do "absurdo", não só constituírem-se como géneros híbridos que incorporam características trágico-cómicas mas, também, promover, quer uma maior generalização no guião - sendo que as personagens, as situações, a acção, as falas, se orientam segundo o critério abstracto do "em geral" (Kierkegaard 2009 [1848]: 64) - quer uma maior imprevisibilidade ${ }^{57}$, levando a que a reação do espectador seja também imprevisível, traduzindo múltiplos estados de espírito, da tristeza e ansiedade até à euforia ${ }^{58}$, ou hoje, mais frequentemente, à indiferença, pois como nos diz Meyer "há muito tempo que as comédias já não fazem rir, nem as tragédias, chorar" (Meyer 2007: 46).

Assumindo este enquadramento em tom de farsa o "guião revolucionário" usado nas diversas formas com que o a(r)tivismo hoje procura ter ou dar voz no espaço público, é palco privilegiado para múltiplas reações e efeitos. Sendo configurado a partir da "indeterminação das identidades, da deslegitimação das posições das palavras, da desregulação das partilhas do espaço e do tempo" (Ranciére 2005: 18), nalguns casos, as suas ações, surgem como inofensivas, toleradas, noutras, são apagadas, rasuradas, silenciadas, classificadas como "de mau gosto" ou infringindo "regras e leis" e, por isso, puníveis. Nuns casos, produzem festa, noutras, terror

56 A frase original é: "Hegel observa algures que todos os grandes factos e personagens da história universal aparecem como que duas vezes. Mas esqueceu-se de acrescentar: uma vez como tragédia e a outra como farsa”(1982:21). 57 Incorporando no seu reportório, por exemplo, diferenças de estatuto social das personagens (do personagem notável ao comum mortal), do tipo de linguagem (erudito e vulgar), do final (infeliz, feliz), da ação (queda e ascensão), tema (engano que triunfa ou é descoberto).

58 Kierkegaard refere que a farsa pode levar o espetador a assumir um estado de "espírito triste" ou ficar "fora de si de tanto rir" (Kierkegaard 2009 [1848]: 64). 
e medo, com toda a panóplia de afecções que esses estados produzem. Em qualquer dos casos, o retorno de um "guião revolucionário", que atravessa os exemplos apresentados ${ }^{59}$, com este carácter fantasmático das revoluções e tragédias do passado, parece corroborar a afirmação com que a socióloga Avery Gordon fecha o seu livro Ghostley Matters (2008) onde nos diz que algumas pessoas acreditam que "os fantasmas não gostam de coisas novas" e, por isso, sublinha, se a injustiça for eliminada, talvez possamos deixar de ser assombrados pelos fantasmas do passado.

\section{Bibliografia}

Alexander, Jeffrey C. 2006 "Cultural Pragmatics: Social Performance between ritual and strategy". In Social Performance - Symbolic Action, Cultural Pragmatics and Ritual. Jeffrey C.Alexander, Bernhard Giesen, Jason L. Mast, 28-89, Cambridge: University Press.

Appadurai, Arjun. 1981 “The past as a Scarce resource”. In Man (N.S), 16(2), 201-219. 2004 (1996) Dimensões Culturais da Globalização. Lisbon: Teorema.

2008 "The capacity to aspire: culture and the terms of recognition". In Cultural Politics in a Global Age - Uncertainty, Solidarity, and Innovation. David Held e Henrietta L. Moore (Eds.), 29-35, Oxford: One World.

Bauman, Zygmunt. 2008 "Living in Utopia”. In Cultural Politics in a Global Age - Uncertainty, Solidarity, and Innovation. David Held e Henrietta L. Moore (Eds.), 346-357, Oxford: One World.

Berman, Marshall. 1989 Tudo o que é Sólido se Dissolve no Ar. Lisbon: Edições 70.Calabrese, Omar. 1999 (1987) A Idade Neobarroca. Lisboa: Edições 70.

Calabrese, Omar. 1999 (1987) A Idade Neobarroca. Lisbon: Edições 70.

Campos, Ricardo, 2013 Introdução à Cultura Visual - Abordagens e metodologias em Ciências Sociais, Colecção Questões de partida, Mundos Sociais: Lisboa. 2015 Ensaio Visual -“A Luta Voltou ao Muro”, Análise Social, No212, XLIX (3.).

Chollet, Laurent. 2004 Les Situationnistes - L’utopie incarnée, Paris: Gallimmard.

Carvalho, Cláudia "Museu do Chiado esteve ocupado toda a noite contra a situação actual na Cultura”. Jornal Público de 06/07/2014.

Cauter, Lieven De Cauter, 2011 "Notes on Subversion/Theses on Activism. In Art and Activism in the Age of Globalization, Lieven De Cauter, Ruben De Roo \& Karel Vanhaesebrouk (Eds.), NAI Publishers:Rotterdam, pp.8-18.

Domenach, Jean-Marie. 1967. Le Retour du Tragique, Paris: Éditions du Seuil.

Debord, Guy 1991 [1967], A Sociedade do Espectáculo, Lisboa: mobilis in mobile.

Edelman, Murray. 1995 From art to politics: how artistic creations shape political conceptions, Chicago: University of Chicago Press.

Gil, José. 2005. Portugal, Hoje - O Medo de Existir. Lisboa: Relógio de Água: (10a edição).

Gohn, Maria da Glória. 2011 "Movimentos sociais na contemporaneidade”, in Revista Brasileira de Educação, V.16, no 47, Maio-Agosto, pp. 333- 361.

Goffman, Erving. 1993 [1959]. A Apresentação do Eu na Vida de Todos Os Dias". Lisboa: Relógio D’Água.

Gordon, Avery F. 2008 Ghostly Matters - Haunting and the sociological Imagination, University of Minnesota Press: Minneapolis, London.

59 Que deambulam entre arte e social (nem todos artísticos ou representando performances políticas artívistas). 
Hamiche, Daniel. 1973 Le thétre et la Révolution - la lutte de classes au théatre en 1789 et en 1793, Union Générale D’Éditions: Paris.

Harvey, David. 2008 New Left Review, 53, Sep-Oct., pp. 23-40.

Heilbrunn, Benoît (dir.). 2004. La performance, une nouvelle idéologie? Critique et enjeux. Paris, Éd. La Découverte.

Henriques, Júlio. 1997 Internacional Situacionista: Antologia, organização, tradução, notas e prefácio de Júlio Henriques, Lisboa: Edições Antígona: Lisboa.

Higgie, Jennifer. 2012 "Shouts \& Murmurs - Art's disputed relationship to activism”. In Frieze -Art and Activism, no149, Sept., p.13.

Juris, Jeffrey S.; Ronayne, Michelle; Shokooh-Valle, Firuzeh; Wengronowitz, Robert. 2012. "Negotiating Power and Difference within the 99\%, Social Movements Studies: Journal of Social", in Cultural and Political Protest, 11:3-4, pp. 434-440.

Kierkegaard, Søren 2009 [1848] A Repetição. Lisboa: Relógio D’Água.

Loxley, James. 2007 "From the Performative to the Speech Act: J. L. Austin". In Performativity (The New Critical Idiom), Routledge: USA and Canada, pp.6-21.

Madeira, Cláudia. 2008. O Hibridismo nas Artes em Portugal. Tese de Doutoramento. Repositório da Universidade de Lisboa.

. 2012. "The 'return' of performance art from a glocal perspective". Cadernos de Arte $e$ Antropologia. Dossiê "Juventude e práticas culturais nas metrópoles" Vol. 1, No 2 , pp.87102 ,

Magalhães, Pedro; Aguiar- Conraria, Luís; Soares, Maria Joana. 2012. "Cycles in Politics: Wavelet Analysis of Political Time Series”, in American Journal of Political Science, 56-2, pp. 500-518.

Maffesoli, Michael. 2001. O Eterno Instante - O Retorno Trágico nas Sociedades Pós-Modernas, Institute Piaget: Lisboa.

Marx, Karl. 1984. O 18 de Brumário de Louis Bonaparte, Lisboa-Moscovo: Edições Avante.

Meyer, Michel 2007. Le Comique et le Tragique. Paris: PUF.

Phelan, Peggy. 2006. Unmarked - The Politics of Performance. London and New York: Routledge.

Pinharanda, João. 2005. "Monumentos em Lisboa de 1974 aos nossos dias: enquadramento teórico, político urbano”. In ArtePública - Roteiro Estatuária e Escultura de Lisboa, 40-47, Lisbon: Câmara Municipal de Lisboa - Pelouro da Cultura.

Raison, David. 2009. “Are 'Smart Mobs' the New New Social Movements?. In david.raison.lu/ raison_2009_social_movements.pdf.

Ranciére, Jaques, 2005 A Partilha do Sensível, São Paulo: Edit. 34 Ltda.

Romão, Rui. 2014. Ensaio de Artivismo - Video e Performance, MNAC-Museu do Chiado, Lisboa. Rogof, Irit; Schneider, Floran. 2008 "Produtive Antecipation". In Cultural Politics in a Global Age - Uncertainty, Solidarity, and Innovation. David Held e Henrietta L. Moore (Eds.), 346-357, Oxford:One World.

Schechner, Richard. 2003. Performance Studies - an introduction. London and New York: Routledge.

Sorokin, Pitirim. 1962 Dinâmica Social e Cultural. Madrid: Ed.Instituto de Estúdios Políticos.

-1957 Social E Cultural Dynamics: a study of change in major sytems of art, truth, ethics, law and social relationships. Boston: Porter Sargent.

Taylor, Diana. 2003. The Archive and Repertoire - Performing Cultural Memory in the Americas, Durham and London, Duke University Press.

Taussig, Michael. 1993 Mimesis and Alterity - A Particular History of the Senses. Routledge: New York, London. 
Turner, Victor (1989). “Are there universals of performance in myth, ritual, and drama?". In By Means of Performance, Richard Schechner and Willa Appel, Great Britain (Eds.), Cambridge University Ubersfeld, Anne (2010). Os Termos-Chave da Análise Teatral. Lisboa: Editora Licorne Press, pp.8-18.

Vieira, Manuel João; Proença, Pedro. 2010, Livro Rosé de sua santidade o camarada Presidente Vieira - recolha, selecção de textos, conspiração e edição de Pedro Proença, Assírio \& Alvim: Lisboa, 2010.

Zizek, Slavoj. 2010. Da Tragédia à Farsa, Lisboa: Relógio d’Água.

\section{"What I WANT IS A REVOLUTION!": THE PERFORMATIVITY OF A SLOGAN}

Written in the first person, this article is part of my personal testimony, of my experience as a citizen and social researcher, with regard to the social environment faced from 2008 to the present in Portugal, especially Lisbon, but also in the cities of Porto, Guimarães and Évora. It involves a context of social, economic and political crisis that has been (re-)inventing and restoring some of the characteristics of the revolutionary mindscape of 25 April 1974. The latter is presented as a "script" ready to use, though also to reinvent and challenge. This environment was created (Harvey 2008), experienced and felt by citizens in their relationship with public space - which includes streets, cultural spaces and the social networks on the internet. Today, it is imbued by an intense performativity, which is punctuated by the emergence of performativity-based activist/"artivist" manifestations (with varying degrees of social change), as well as processes that institutionally erase or silence these very manifestations. It is this dialectic that I intend to examine in my testimony, which is essentially based on "empirical" observation that stems from my daily life and my experience as a "spectator".

Keywords: artivism, performance, performativity, new social movements, "revolutionary script"

Recebido em: 2014-01-31

Aceitado em: 2015-09-19 